\title{
Home is where it happens: a visual essay on pandemic parenting for employed mothers
}

\author{
Monica Heilman, Indiana University \\ Jessica McCrory Calarco, Indiana University
}

\begin{abstract}
Amidst the COVID-19 pandemic, many U.S. schools, childcare centres, and non-essential workplaces closed or moved to a virtual, remote format. As a result, many families were forced to combine childcare, schooling, and paid work responsibilities within the home. This shift had unequal consequences, with employed mothers often bearing the brunt of additional childcare and household labour. In this visual essay, we draw from in-depth interviews with mothers of young children $(\mathrm{N}=65)$, conducted in the early stages of the pandemic (April-May 2020) to produce three illustrations. As an analytic tool and form of data representation, these illustrations portray the experiences of employed mothers, situate these experiences within the broader institutional contexts of the pandemic, and use visual elements designed to leave layers of meaning up to audience interpretation.
\end{abstract}

Keywords: childcare, covid-19, parenting, families, arts-based research

To cite this article: Monica Heilman \& Jessica Calarco (2022): Home is where it happens: a visual essay on pandemic parenting for employed mothers, Visual Studies, DOI: 10.1080/1472586X.2022.2032818

To link to this article: https://doi.org/10.1080/1472586X.2022.2032818 


\section{Pandemic parenting and gender inequalities}

In March 2020, COVID-19 rates in the US increased rapidly, leading many childcare centers, schools, and non-essential workplaces to close or shift to remote format. These changes disrupted daily life for many Americans, especially employed mothers. Even before the pandemic, employed mothers did a disproportionate share of housework and childcare (Collins 2019; Damaske 2011). Pandemic-related disruptions exacerbated these inequalities and also led employed mothers to disproportionately reduce their paid work hours, drop out of the workforce, and report increased anxiety and depression (Carlson et al. 2020; Collins et al. 2020; Landivar et al. 2020; Lyttelton, Zang, and Musick 2020). In this visual essay, we use illustrations to depict the experiences of employed mothers during the COVID-19 pandemic and visualize the external forces currently shaping their lives.

\section{Why art?: illustrating pandemic lives}

Scholars have long recognized images as rich sources of data (Becker, 1974; Getz, 1988; Olien, 1968; Signorile, 1988) and more recently, acknowledged the value of integrating artsbased practices into research (Bhattacharya, 2013; Harper, 2012; Heng, 2016; Leavy, 2017). Academic scholarship privileges written words (Becker, 2000), yet visual media can also contextualize social phenomena, speed up or enhance data collection, and convey information in varied and more impactful ways (Becker, 1974, 2000; Harper, 2012, 2016). Drawing, for example, is a powerful tool for meaning-making and can generate new understandings through choices about composition, style, and medium (Sousanis 2015). Essentially, arts-based research 
operates akin to film adaptations of novels, building on the original written work to offer new insights (Leavy 2020). Through that adaptation process, artwork can also communicate scientific findings to audiences outside of academia, making them more accessible than standard journal articles and potentially increasing the likelihood that research-based insights will be applied in organizations, policies, and individual lives (Becker, 2000; Leavy, 2020).

Visual art is especially effective for capturing employed mothers' experiences during the COVID-19 pandemic. The shift to remote work and remote learning limited many pandemic interactions to 2D screens (Fauville et al., 2021). The images cultivated to appear in Zoom screens, however, often contradict the messy realities behind the scenes, as depicted in Adrian Tomine's New Yorker cover 'Love Life' (Tomine 2020). While Tomine's illustration depicts a woman on a virtual date, this contradiction between cultivated appearance and reality may be even starker for employed mothers attempting to appear professional while caring for children. Thus, just as Tomine's illustration offered an affirming touchstone for many viewers (Moran, 2020; Ritschel, 2020), we hope our illustrations will offer similarly relatable depictions of employed mothers' experiences managing childcare and paid work

\section{Methods}

The artwork in this visual essay draws on data from Wave 1 of the Pandemic Parenting Study (PPS), a mixed-method, longitudinal study of mothers of young children in Southern Indiana. Conducted in April and May 2020, Wave 1 includes surveys ( $=139)$ and in-depth interviews $(\mathrm{N}=65)$. In this paper, we focused on one theme previously identified by the second author: the impact of school and childcare center closures on employed mothers' well-being (Calarco et al., 2020). The second author identified interview quotes that illustrated this theme, 
which the first author analyzed through sketches and analytic memos considering message, art medium, and style. The authors discussed these sketches and memos and used them to develop a plan for the final illustrations which the first author drew and paired with relevant interview quotes.

\section{Depicting Disruptions}

Our illustrations reveal how the COVID-19 pandemic has 1) eroded institutional support for employed mothers, 2) reconstructed the home as both the center of pandemic life and a site of crowded isolation that exacerbated the pressures of parenting and paid work, and 3) eroded employed mothers' sense of identity as workers and mothers.

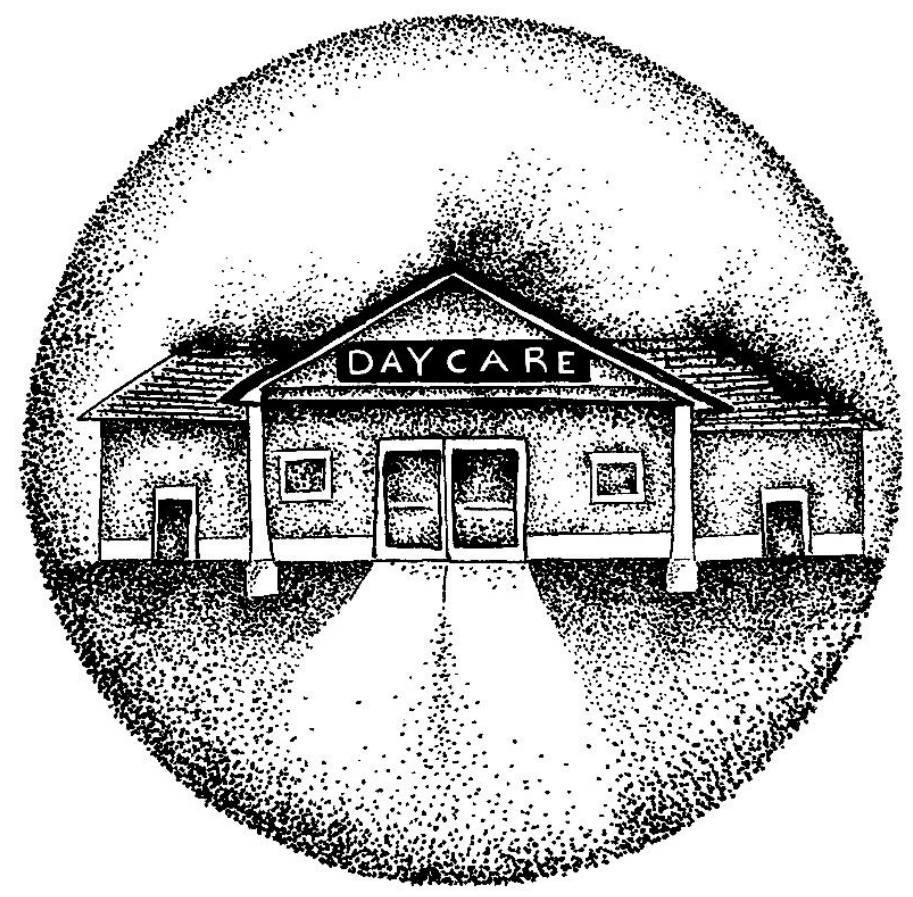

Figure 1. Daycare centre. 


\section{Eroded Institutions}

Sabrina: “On Friday I had to drive [my four-year-old] past [her preschool], because she had a little bit of a breakdown about, 'I don't know what my preschool looks like and I don't remember what my teacher looks like.' I said, 'Okay, I will drive you past these places and you cannot go in them, but I'll drive you past these places?'... Her preschool was open for the first probably week and a half [of the pandemic], but then they closed down. So it's only been three weeks of her at home and it's finally hit her."

Sabrina is a part-time athletic trainer and adjunct instructor; her husband works full-time in nonprofit fundraising. The family's preschool/childcare center closed during the early stages of the pandemic, leaving Sabrina primarily responsible for childcare at home. That care included helping her daughter process the loss of an institution that was central to the family's identity and sense of routine. While intact, the childcare center in Figure 1 is surrounded by particles that might be read as a virus. The image is intentionally ambiguous, leaving the audience to determine whether the building is simply surrounded or being eroded by these particles.

\section{Crowded isolation}

Erica: '[The kids] get up early, so by 8:00, that's hour 13 nonstop togetherness, and I think at that point I'm done.... I feel like my patience with the kids, there's been days where it's really good and days when it just hasn't been great at all, and I just feel like oh my gosh, I can't believe we have to do this for how many more months. It's that every day the house gets destroyed, toys everywhere, and then we've got to clean it all up.' 
'My husband's job is very demanding, and they talk a lot about flexibility, but at the end of the day if [his boss] sets a meeting, he sets a meeting. You can't not go, even during a pandemic, if you want to keep your job... [So] it's primarily me.'

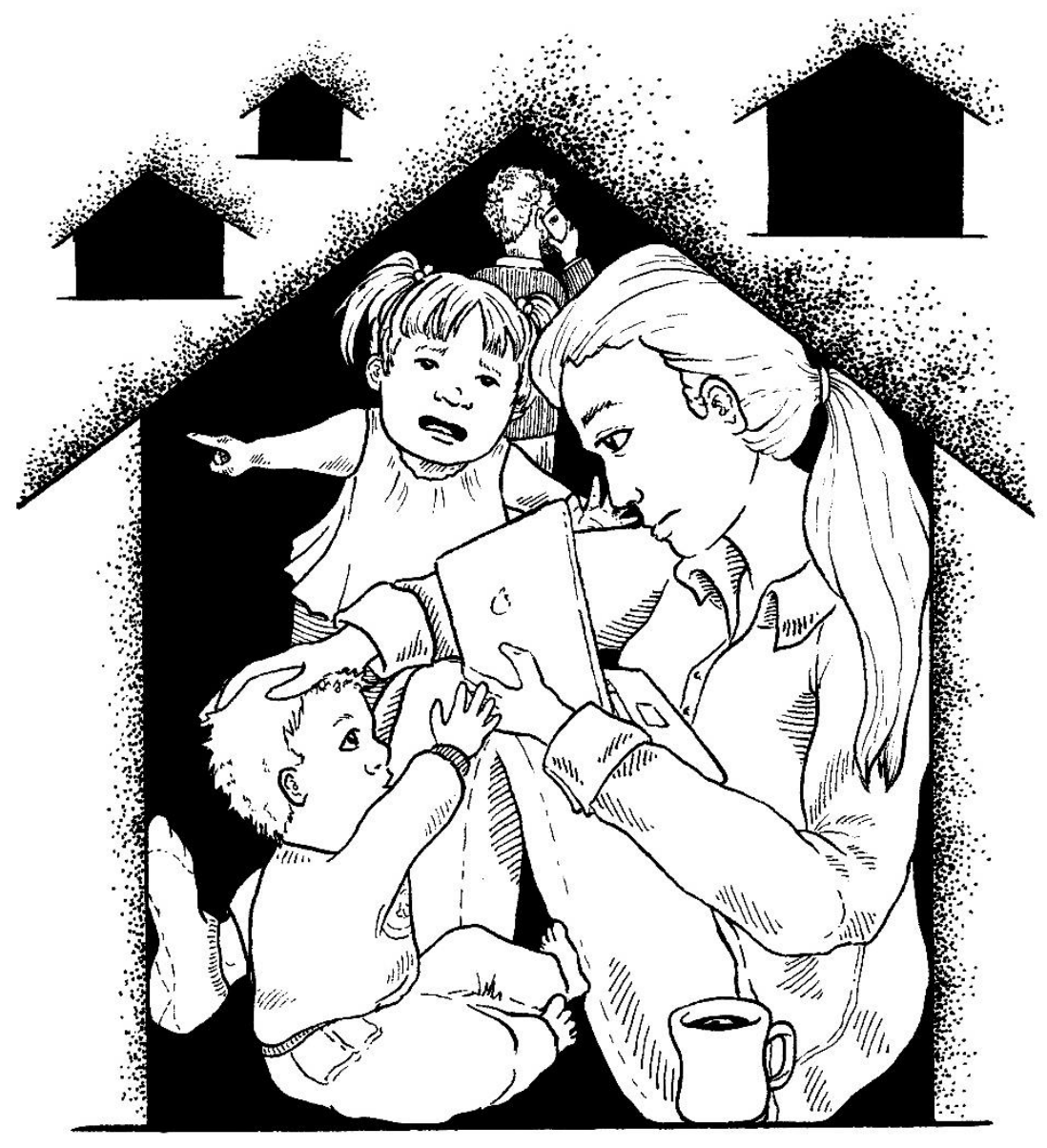

Figure 2. The home as centre.

During the pandemic, Erica, a data analyst, reduced her paid work to just two hours a day and became the primary caregiver for her first-grader, preschooler, and toddler. Her husband continued working full-time in marketing, holing himself up in their bedroom to work uninterrupted during the day. Figure 2 depicts these imbalanced responsibilities and the context 
in which they occurred. The home is construed as a space safe from the virus, yet families are forced to live in a crowded isolation that comes with substantial stressors.

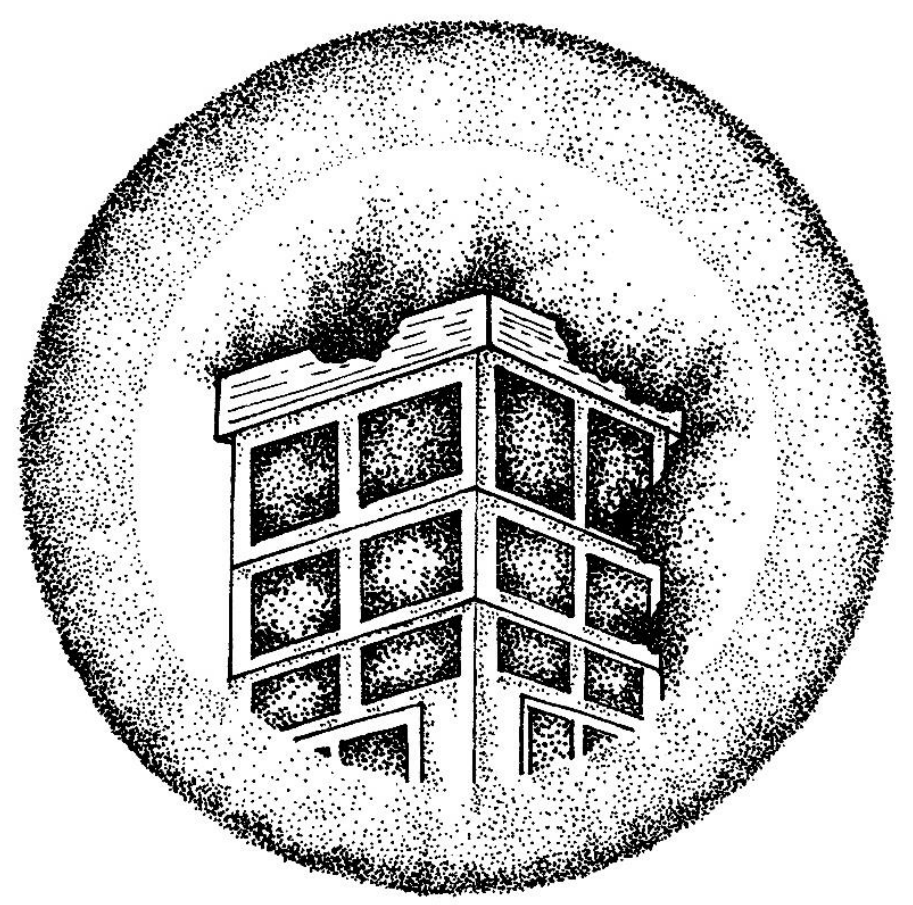

Figure 3. Office building.

\section{Eroded identities}

Gina: 'The hardest thing is just suddenly feeling I'm not getting any work done. Somehow I'm not getting any work done, but also [my daughter] is not getting the best mothering she could be getting. It's like wait a second. Where did all that energy go, if it's not going into work and not going into her? All of a sudden I'm not doing a good job of either.' 
Laura: 'It's a day by day thing, trying to get it figured out, having to work in the evenings, on the weekends. I mean, it definitely does stink. On the one hand, it's kind of fun being home and being around the kids more often, but yeah, like I said, it's tough. You use childcare for a reason so that you can get things done.'

Gina, a full-time lawyer, and Laura, a full-time marketing manager, were both telecommuting while caring for children whose schools/childcare centers had closed. Figure 3 captures the loss of dedicated workspace and the resulting loss of employed mothers' identities as workers. It also speaks to research showing that women reduced their workhours and left the workforce at much higher rates than men (Collins et al., 2020; Landivar et al., 2020). The image of the office building mirrors the daycare in Figure 1, with its circular frame and virus-like stippling. Yet, unlike the childcare center, this office building, symbolizing work, has clearly been eroded.
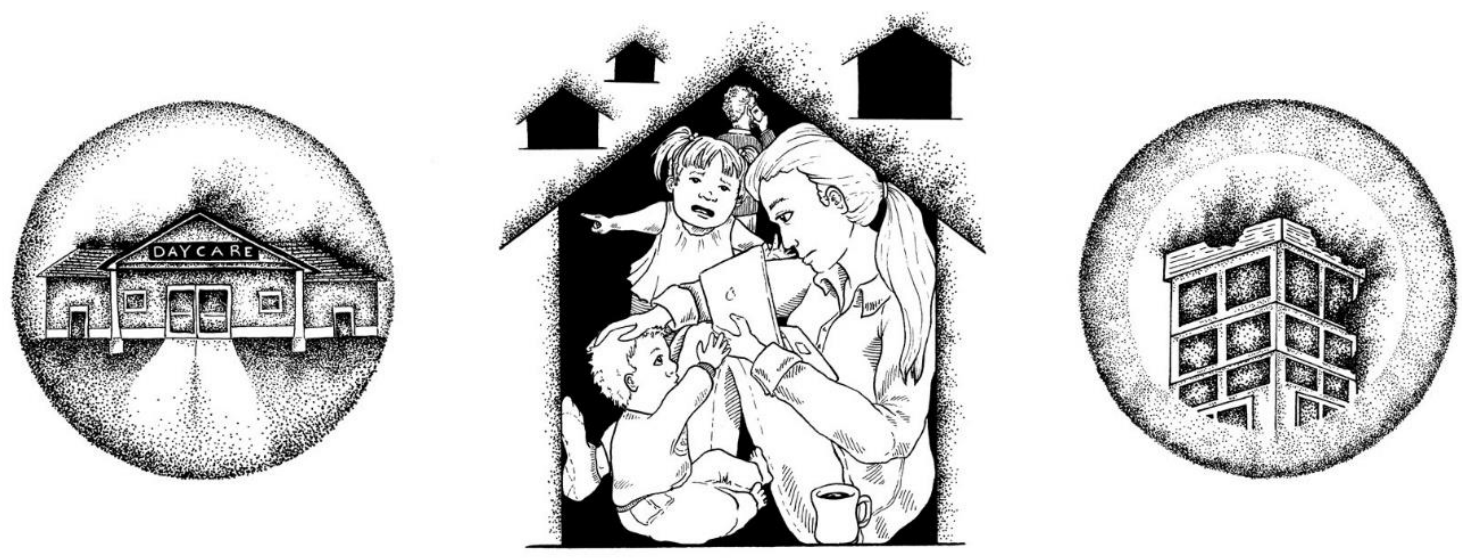

Figure 4. 


\section{Conclusion}

Building on evidence from interviews with mothers of young children (Calarco et al., 2020), the illustrations in this essay reveal how pandemic-related disruptions to families' paid work and childcare arrangements have 1) eroded institutional support for employed mothers, 2) reconstructed the home as both the center of pandemic life and a site of crowded isolation that exacerbated the pressures of parenting and paid work, and 3) eroded employed mothers' sense of identity as workers and mothers.

These visualizations bring new meaning not only to the source data but also to patterns of gender inequalities found in other pandemic research (Carlson et al., 2020; Collins et al., 2020; Landivar et al., 2020). In doing so, this paper also shows how artwork can represent data in engaging ways (Bhattacharya, 2013; Hunter et al., 2002) and uncover new meanings, insights, or connections (Vaart et al., 2018; Yorks \& Kas1, 2006). 


\section{References}

Becker, H. S. 1974. "Photography and Sociology." Studies in the Anthropology of Visual Communication 1 (1): 3-26.

Becker, H. S. 2000. "What Should Sociology Look Like in the (Near) Future?” Contemporary Sociology 29 (2): 333-336.

Bhattacharya, K. 2013. "Voices, Silences, and Telling Secrets: The Role of Qualitative Methods in Arts-Based Research.” International Review of Qualitative Research 6 (4): 604- 627.

Calarco, J. M., E. M. Anderson, E. V. Meanwell, and A. Knopf. 2020. 'Let's Not Pretend It's Fun": How COVID-19- Related School and Childcare Closures are Damaging Mothers' Well-Being.

Carlson, D. L., R. Petts, and J. R. Pepin. 2020. “US Couples’ Divisions of Housework and Childcare during COVID-19 Pandemic [Preprint]." SocArXiv.

Collins, C. 2019. Making Motherhood Work: How Women Manage Careers and Caregiving. Princeton: Princeton University Press.

Collins, C., L. C. Landivar, L. Ruppanner, and W. J. Scarborough. 2020. “COVID-19 and the Gender gap in Work Hours." Gender, Work \& Organization 28: 101-112.

Damaske, S. 2011. For the Family?: How Class and Gender Shape Women's Work. New York: Oxford University Press.

Fauville, G., M. Luo, A. C. Muller Queiroz, J. N. Bailenson, and J. Hancock. 2021. Nonverbal Mechanisms Predict Zoom Fatigue and Explain Why Women Experience Higher Levels than Men (SSRN Scholarly Paper ID 3820035). Social Science Research Network.

Getz, J. G. 1988. "Visual Sociology as the Illustration of Theory: Report from the American Sociological Association: Meetings, August 1988." Visual Sociology 3 (2): 10-11. 
Harper, D. 2012. Visual Sociology. London: Taylor \& Francis Group.

Harper, D. 2016. "The Development of Visual Sociology: A View from the Inside." SocietàMutamentoPolitica 7 (14): 237-250.

Heng, T. 2016. Visual Methods in the Field: Photography for the Social Sciences. New York: Routledge.

Hunter, A., P. Lusardi, D. Zucker, C. Jacelon, and G. Chandler. 2002. "Making Meaning: The Creative Component in Qualitative Research.” Qualitative Health Research 12 (3): 388398.

Landivar, L. C., L. Ruppanner, W. J. Scarborough, and C. Collins. 2020. "Early Signs Indicate that COVID-19 Is Exacerbating Gender Inequality in the Labor Force.” Socius 6: 1-3.

Leavy, P., ed. 2017. Handbook of Arts-Based Research. New York: Guilford Press.

Leavy, P. 2020. Method Meets Art, Third Edition: Arts-Based Research Practice. 3rd ed. New York: The Guilford Press.

Lyttelton, T., E. Zang, and K. Musick. 2020. "Gender Differences in Telecommuting and Implications for Inequality at Home and Work.” SocArXiv. https://doi.org/ 10.31235/osf.io/tdf8c

Moran, L. 2020. 'New Yorker Cover Goes Viral Because It's 'So Damn Relatable' for 2020.” HuffPost. December 4.

Olien, M. D. 1968. "Visual Anthropology: Photography as a Research Method. JOHN COLLIER, JR.” American Anthropologist 70 (4): 837-837.

Ritschel, C. 2020. 'New Yorker Cover Goes Viral for Being 'Relatable' Depiction of Life in the Pandemic." The Independent. December 1. 
Signorile, V. 1988. "Signs and Symbols: An Exploration of the Use of Visuals as Data." Visual Sociology 3 (1): 9-14.

Sousanis, N. 2015. Unflattening. Cambridge, Massachusetts: Harvard University Press.

Tomine, A. 2020. Love Life [Illustration]. The New Yorker. https://www.newyorker.com/culture/cover-story/coverstory- 2020-12-07

van der Vaart, G., B. van Hoven, and P. P. P. Huigen. 2018. "Creative and Arts-Based Research Methods in Academic Research. Lessons from a Participatory Research Project in the Netherlands." Forum Qualitative Sozialforschung / Forum: Qualitative Social Research 19 (2): Article 2.

Yorks, L., and E. Kasl. 2006. "I Know More Than I Can Say: A Taxonomy for Using Expressive Ways of Knowing to Foster Transformative Learning." Journal of Transformative Education 4 (1): 43-64. 